Volume 6 Issue 2, 2020

P-ISSN : 2460-5697, E-ISSN : 2655-2906

Website: https://www.jurnal-umbuton.ac.id/index.php/Pencerah

\title{
Analisis Lokasi Potensial Ruang Terbuka Hijau di Kota Baubau
}

\author{
1Andrianto Arifin
}

Email: andriantoarifin@gmail.com

\begin{abstract}
Abstrak
Penelitian ini bertujuan untuk mendeskripsikan lokasi dan areal ruang terbuka hijau disekitar perkantoran, sekolah, pemukiman di Kota Baubau dan mendeskripsikan lokasi dan areal ruang terbuka untuk hutan kota dan taman kota di kota Baubau. Teknik analisis data yang dihunakan adalah analisis deskriptif. Hasil penelitian ini menunjukkan bahwa luas ruang terbuka hijau di sekitar perkantoran, sekolah, pemukiman, berkisar antara 10\%-50\% dari luas bangunan. Untuk luas areal ruang terbuka untuk hutan dan taman kota berkisar 10\%-50\% dari luas lahan perkotaan yang termanfaatkan. Untuk bentuk RTH disekitar perkantoran, sekolah, pemukiman, dan taman kota adalah bentuk lingkaran, leter $U$, Leter L, jalur, segitiga, bujur sangkar. Untuk bentuk hutan kota adalah menyebar, jalur, bergerombolan, untuk vegetasi di sekitar bangunan perkantoran, sekolah, pemukiman adalah rumput, bunga, pohon perdu, pohon toga, pohon yang berbuah. Untuk vegetasi hutan dan taman kota adalah rumput, bunga, palem, mahoni, tanjung, flamboyan, pinus. Untuk hewan yang ada di RTH di sekitar perkantoran, sekolah, pemukiman dan taman kota adalah burung, serangga, dan ikan hias dan untuk hutan kota adalah burung, serangga, rusa. Jarak dari pemukiman masyarakat dengan hutan kota adalah $0,3 \mathrm{~km}$ sampi $5 \mathrm{~km}$.
\end{abstract}

Keywords: Lokasi Potensial; Ruang Terbuka Hijau (RTH)

\begin{abstract}
This study aims to describe the location and area of green open space around offices, schools, settlements in the City of Baubau and to describe the locations and areas of open space for urban forests and urban parks in the city of Baubau. The data analysis technique used is descriptive analysis. The results of this study indicate that the area of green open space around offices, schools, settlements, ranges from $10 \%-50 \%$ of the building area. The area of open space for forest and city parks is around $10 \%-50 \%$ of the utilized urban land area. For the form of green open space around offices, schools, settlements, and city parks, it is a circle, a $U, L$, a lane, a triangle, a square. For the form of urban forest is spread, path, clustered, for vegetation around office buildings, schools, settlements are grass, flowers, shrubs, toga trees, fruiting trees. For forest and city park vegetation are grass, flowers, palms, mahogany, headlands, flamboyant, pine. For animals in GOS around offices, schools, settlements and city parks are birds, insects, and ornamental fish and for urban forests are birds, insects, deer. The distance from community settlements to urban forest is $0.3 \mathrm{~km}$ to $5 \mathrm{~km}$.
\end{abstract}

Kata kunci: Potential Location; Green Open Space (GOS)

\footnotetext{
${ }^{1}$ SMAS Muhammadiyah, Baubau-Indonesia
} 


\section{PENDAHULUAN}

Kota merupakan pemusatan tempat tinggal dan kegiatan manusia yang tetap. Pada umumnya kota bersifat multi fungsional, artinya untuk banyak kegiatan dan keperluan misalnya sebagai pusat administrasi, pusat perdagangan, tempat tinggal dan lain-lain. Ruang terbuka (open space) pada suatu kota menunjukkan ciri kota yang berkelanjutan. Kota yang berkelanjutan adalah kota yang dapat dihuni dengan nyaman pada saat ini dengan tetap memperhatikan dan mempertahankan kenyamanan manusia yang menghuni kota di masa yang akan datan. Pernyataan seperti yang dikemukakan ini sangat sesuai dengan konsep pembangunan yang berkelanjutan (Brundtland, 1978) yang kesimpulannya menyatakan bahwa pembangunan yang berkelanjutan atau pembangunan yang berkesinambungan adalah pembangunan yang dapat menyediakan kebutuhan generasi masa kini tanpa mengurangi kemampuan generasi mendatang untuk memperoleh kebutuhannya.

$$
\text { Ruang terbuka hijau }
$$
merupakan areal berupa ruang terbuka yang bervegetasi berada dikawasan perkotaan yang mempunyai fungsi perlindungan, pemanfaatan dan pelestarian lingkungan hidup. Fungsi RTH dapat berbentuk hutan kota, taman kota, taman pemakaman umum, lapangan orahraga, bantaran sungai, dan kawasan pertanian. RTH disebut sebagai paru-paru kota karena merupakan produsen oksigen yang belum terbantikan fungsinya. Keberadaan RTH maupun lahan dengan fungsi sejenis diperlukan sebuah arahan pembangunan yang berwawasan lingkungan sebagai usaha untuk meningkatkan kualitas lingkungan hidup di kota Baubau. Meskipun demikian pembangunan RTH di kota Baubau tetap memerlukan perencanaan yang matang dengan pempertimbangkan banyak faktor, antara lain; luas lahan, kondisi tanah, kondisi sosial masyarakat, suhu, dan antisipasi terhadap pencemaran undara yang kesemuanya terkait dengan Rencana Tata ruang Wilayah Kota Baubau.

Kota Baubau yang mempunyai luas daerah $221 \mathrm{~km}^{2}$ merupakan salah satu kota yang mengalami perkembangan cukup pesat pembangunannya. Dengan laju pertambahan penduduk pertahun selama kurun waktu 10 tahun sebesar $2,88 \%$, angka pertambajan imi cukup besar yang disebabkan oleh urbanisasi dari konflik maluku maupun pasca referendum Timor Timur dengna jumlah pendudukan 122.339 jiwa memerlukan perluasan pemukiman, hal ini menyebabkan berubahnya fungsi kawasan bervegetasi menjadi kawasan terbangun.

Permasalahan yang ada di kota Baubau adalah ketersediaan lokasi potensial RTH yang tidak tercukupi, disebabkan oleh alih fungsi peruntukan lahan akibat kebijakan pemerintah daerah. Secara kualitatif lokasi potensial RTH di kota Baubau cenderung menurun sehingga di perlukan berbagai upaya untuk meningkatkan atau mempertahankan keberadaan lokasi potensial RTH yang ada saat ini, oleh karena itu partisipasi aktif masyarakat luas sangat dibutuhkan. Keberhasilan pengembangan RTH ditentukan oleh tingkat partisipasi masyarakat. Partisipasi masyarakat dapat berupa penyediaan lahan untuk RTH dan kesadaran untuk menaman brbagai jenis pohon dilingkungan rumah masing-masing. Proses penyusunan dan perubahan rencana tata ruang wilayah Kota Baubau seharusnya juga melibatkan masyarakat. Dengan kesadaran akan pentingnya keberadaan RTH (Hutan kota dan taman 
Kota) dijadikan tempat rekreasi sebagai laboratorium alam untuk pendidikan dan penelitian.

\section{METODE PENELITIAN}

Penelitian ini dilakukan di Kota Baubau yang terdiri dari atas 6 kecamatan yaitu kecamatan Wolio, Kecamatan Betoambarim, Kecamatan Sorawolio, Kecamatan Bungi, Kecamatan Kokalukuna, Kecamatan Murhum. Metode yand digunakan metode alisisis deskriftif dengan jenis penelitian yaitu penilitian survei. Populasi dalam penelitian ini adalah seluruh masyarakat di Kota Baubau. Penarikan sampel dalam penelitian ini dipilih purposive sampling dengan mengambil sampel dari pihak pemerintah, tokoh masyarakat, akademisi, dan pihak swasta.

\section{HASIL}

Luas areal untuk ruang terbuka hijau disekitar bangungan perkotaan, sekolah, pemukiman di Kota Baubau

Tabel 1. Persen fase luas areal untuk ruang terbuka hijau disekitar bangungan perkotaan, sekolah, pemukiman di Kota Baubau

\begin{tabular}{|c|c|c|c|}
\hline \multicolumn{4}{|c|}{$\begin{array}{c}\text { Luas Areal Ruang Terbuka Hijau Disekitar } \\
\text { Bangunan Perkantoran Di Kota Baubau }\end{array}$} \\
\hline NO & $\begin{array}{l}\text { Luas areal } \\
\text { RTH }(\%)\end{array}$ & Frekwensi & Persentase \\
\hline 1 & $50 \%$ & 7 & 11 \\
\hline 2 & $40 \%$ & 10 & 16,6 \\
\hline 3 & $30 \%$ & 25 & 41,6 \\
\hline 4 & $20 \%$ & 18 & 30,8 \\
\hline & umlah & 60 & 100 \\
\hline \multicolumn{4}{|c|}{$\begin{array}{l}\text { Luas Areal Ruang Terbuka Hijau Disekitar } \\
\text { Bangunan Sekolah Di Kota Baubau }\end{array}$} \\
\hline NO & $\begin{array}{l}\text { Luas areal } \\
\text { RTH }(\%)\end{array}$ & Frekwensi & Persentase \\
\hline 1 & $50 \%$ & 4 & 6,7 \\
\hline 2 & $40 \%$ & 7 & 11,6 \\
\hline 3 & $30 \%$ & 49 & 65 \\
\hline 4 & $20 \%$ & 10 & 16,7 \\
\hline & umlah & 60 & 100 \\
\hline \multicolumn{4}{|c|}{$\begin{array}{c}\text { Luas Areal Ruang Terbuka Hijau Disekitar } \\
\text { Bangunan Pemukiman Di Kota Baubau }\end{array}$} \\
\hline NO & $\begin{array}{l}\text { Luas areal } \\
\text { RTH (\%) }\end{array}$ & Frekwensi & Persentase \\
\hline
\end{tabular}

\begin{tabular}{|c|c|c|c|}
\hline 1 & $50 \%$ & 4 & 6,7 \\
\hline 2 & $40 \%$ & 10 & 16,7 \\
\hline 3 & $30 \%$ & 20 & 33,3 \\
\hline 4 & $20 \%$ & 26 & 43,3 \\
\hline \multicolumn{2}{|c|}{ Jumlah } & 60 & 100 \\
\hline
\end{tabular}
disekitar bangunan perkotaan di kota Baubau 5\%-10\% dari luas lahan dimanfaatkan untuk bangunan fisik. Ada 60 Stakeholder yang dijadikan sampel penelitian yang menyatakan luas areal $50 \%$ ada 7 (11\%) Stakeholder, luas areal $40 \%$ ada $10(16,66 \%)$ Stakeholder, luas areal $30 \%$ ada $25(41,6 \%)$ Stakeholder, luas areal $20 \%$ ada $18 \quad(30,8 \%)$ Stakeholder.

Luas areal ruang terbuka hijau di sekitar bangunan sekolah di kota Baubau 10\%-15\% dari luas lahan di manfaatkan. Ada 60 Stakeholder yang dijadikan sampel penelitian yang menyatakan luas areal $50 \%$ ada $4(6,7 \%)$ Stakeholder, luas areal $40 \%$ ada $7(11,6 \%)$ Stakeholder, luas areal $30 \%$ ada $39(65 \%)$ Stakeholder, luas areal $20 \%$ ada $10(16,7 \%)$ Stakeholder.

Luas areal ruang terbuka hijau disekitar bangunan pemukiman di kota Baubau 5\%-10\% dari luas lahan dimanfaatkan untuk bangunan fisik. Ada 60 Stakeholder yang dijadikan sampel penelitian yang menyatakan luas areal $50 \%$ ada $4(6,7 \%)$ Stakeholder, luas areal $40 \%$ ada $10(16,7 \%)$ Stakeholder, luas areal $30 \%$ ada 20 (33,3\%) Stakeholder, luas areal $20 \%$ ada $26 \quad(43,3 \%)$ Stakeholder.

Tabel 2. Persen fase luas areal untuk ruang terbuka untuk Hutan Kota dan taman kota di Kota Baubau

Luas Areal Ruang Terbuka Untuk Hutan Kota Di Kota Baubau

\begin{tabular}{|c|c|c|c|}
\hline NO & $\begin{array}{c}\text { Luas areal } \\
\text { RTH }(\%)\end{array}$ & Frekwensi & Persentase \\
\hline 1 & $50 \%$ & 5 & 8,3 \\
\hline 2 & $40 \%$ & 10 & 16,7 \\
\hline 3 & $30 \%$ & 24 & 40 \\
\hline 4 & $20 \%$ & 17 & 28,3 \\
\hline 5 & $10 \%$ & 4 & 6,7 \\
\hline & Jumlah & 60 & 100 \\
\hline
\end{tabular}




\begin{tabular}{cccc}
\hline \multicolumn{3}{c}{ Kota Baubau } \\
\hline NO & $\begin{array}{c}\text { Luas areal } \\
\text { RTH (\%) }\end{array}$ & Frekwensi & Persentase \\
\hline 1 & $50 \%$ & 2 & 3,3 \\
\hline 2 & $40 \%$ & 7 & 11,7 \\
\hline 3 & $30 \%$ & 22 & 36,7 \\
\hline 4 & $20 \%$ & 19 & 31,7 \\
\hline 5 & $10 \%$ & 10 & 16,6 \\
\hline & Jumlah & $\mathbf{6 0}$ & $\mathbf{1 0 0}$ \\
\hline
\end{tabular}

Luas areal ruang terbuka untuk hutan kota dikota Baubau menyatakan $30 \%$ dari luas lahan yang termanfaatkan (hasil diskusi FGD). Ada 60 Stakeholder yang dijadikan sampel penelitian yang menyatakan luas areal $50 \%$ ada $5(8,3 \%)$ Stakeholder, luas areal $40 \%$ ada 10 $(16,7 \%)$ Stakeholder, luas areal 30\% ada $24(40 \%)$ Stakeholder, luas areal 20\% ada $17(28,3 \%)$ Stakeholder, luas areal 10\% ada $4(6,7 \%)$.

Luas areal ruang terbuka untuk taman kota dikota Baubau menyatakan $30 \%$ dari luas lahan yang termanfaatkan (hasil diskusi FGD). Ada 60 Stakeholder yang dijadikan sampel penelitian yang menyatakan luas areal $50 \%$ ada $2(3,3 \%)$ Stakeholder, luas areal $40 \%$ ada $7(11,7 \%)$ Stakeholder, luas areal $30 \%$ ada 22 $(36,7 \%)$ Stakeholder, luas areal 20\% ada $19(31,7 \%)$ Stakeholder, luas areal 10\% ada $10(16,6 \%)$.

Adapun bentuk RTH disekitar bangunan perkantoran, bangunan sekolah, bangunan pemukiman adalah:

Tabel 3. Bentuk RTH Disekitar Bangunan Perkantoran, Bangunan Sekolah, Bangunan Pemukiman

\begin{tabular}{|c|c|c|c|}
\hline \multicolumn{4}{|c|}{ Bentuk RTH disekitar bangunan Perkantoran } \\
\hline NO & Bentuk RTH & Frekwensi & Persentase \\
\hline 1 & Lingkaran & 17 & 28,3 \\
\hline 2 & Bujur Sangkar & 8 & 13,3 \\
\hline 3 & Leter L & 12 & 22 \\
\hline 4 & Leter U & 12 & 22 \\
\hline 5 & Jalur & 11 & 18,3 \\
\hline & Jumlah & 60 & 100 \\
\hline \multicolumn{4}{|c|}{ Bentuk RTH disekitar bangunan sekolah } \\
\hline NO & Bentuk RTH & Frekwensi & Persentase \\
\hline 1 & Lingkaran & 10 & 16,7 \\
\hline 2 & Bujur Sangkar & 8 & 13,3 \\
\hline 3 & Leter L & 12 & 22 \\
\hline 4 & Leter U & 20 & 33,3 \\
\hline
\end{tabular}

\begin{tabular}{clcc}
\hline 5 & Jalur & 10 & 16,7 \\
\hline & Jumlah & $\mathbf{6 0}$ & $\mathbf{1 0 0}$ \\
\hline \multicolumn{2}{c}{ Bentuk RTH disekitar bangunan pemukiman } \\
\hline NO & Bentuk RTH & Frekwensi & Persentase \\
\hline 1 & Lingkaran & 15 & 25 \\
\hline 2 & Bujur Sangkar & 6 & 10 \\
\hline 3 & Leter L & 12 & 20 \\
\hline 4 & Leter U & 13 & 21,6 \\
\hline 5 & Jalur & 14 & 23,4 \\
\hline & Jumlah & $\mathbf{6 0}$ & $\mathbf{1 0 0}$
\end{tabular}

Bentuk ruang terbuka disekitar bangunan perkantoran di kota Baubau adalah Bentuk lingkaran. Ada 60 Stakeholder yang dijadikan sampel penelitian yang menyatakan bentuk lingkaran 17 (28,3\%) Stakeholder, bentuk bujur sangkar 8 (13,3\%) Stakeholder, bentuk Leter L 12 (22\%) Stakeholder, bentuk Leter U 12 (18,3\%) Stakeholder, bentuk jalur 11 (18,3\%).

Bentuk ruang terbuka disekitar bangunan sekolah di kota Baubau adalah Bentuk jalur. Ada 60 Stakeholder yang dijadikan sampel penelitian yang menyatakan bentuk lingkaran 10 (16,7\%) Stakeholder, bentuk bujur sangkar 8 (13,3\%) Stakeholder, bentuk Leter L 12 (22\%) Stakeholder, bentuk Leter U 20(33,3\%) Stakeholder, bentuk jalur 10 $(16,7 \%)$.

Bentuk ruang terbuka disekitar bangunan pemukiman di kota Baubau adalah Bentuk bujur sangkar. Ada 60 Stakeholder yang dijadikan sampel penelitian yang menyatakan bentuk lingkaran 15 (25\%) Stakeholder, bentuk bujur sangkar 6 (10\%) Stakeholder, bentuk Leter L 12 (20\%) Stakeholder, bentuk Leter U 13(21,6\%) Stakeholder, bentuk jalur 14 (23,4\%).

Tabel 4. Bentuk Hutan dan Taman Untuk Ruang Terbuka

\begin{tabular}{|c|c|c|c|}
\hline \multicolumn{4}{|c|}{ Bentuk Hutan Untuk Ruang Terbuka } \\
\hline NO & Bentuk RTH & Frekwensi & Persentase \\
\hline 1 & Jalur & 20 & 33,3 \\
\hline 2 & Menyebar & 35 & 58,3 \\
\hline 3 & Bergerombol & 5 & 8,4 \\
\hline & Jumlah & 60 & 100 \\
\hline \multicolumn{4}{|c|}{ Bentuk Taman Untuk Ruang Terbuka } \\
\hline NO & Bentuk RTH & Frekwensi & Persentase \\
\hline
\end{tabular}




\begin{tabular}{llll}
\hline 1 & Lingkaran & 20 & 33,3 \\
\hline 2 & Bergerombol & 14 & 23,3 \\
\hline 3 & Bujur Sangkar & 10 & 16,7 \\
\hline 4 & Jalur & 16 & 26,7 \\
\hline & Jumlah & $\mathbf{6 0}$ & $\mathbf{1 0 0}$ \\
\hline
\end{tabular}

Bentuk hutan kota untuk ruang terbuka ditiap kecamatan di Kota Baubau adalah bentuk jalur. Ada 60 Stakeholder yang dijadikan sampel penelitian yang menyatakan bentuk jalur $20 \quad(33,3 \%)$ Stakeholder, bentuk menyebar 35 (58,3\%) Stakeholder, bentuk bergerombol $5(8,4 \%)$ Stakeholder.

Bentuk taman kota untuk ruang terbuka di Kota Baubau adalah bentuk lingkaran. Ada 60 Stakeholder yang dijadikan sampel penelitian yang menyatakan bentuk lingkaran 20 (33,3\%) Stakeholder, bentuk bergerombol 14 $(23,3 \%)$ Stakeholder, bentuk bujur sangkar 10 (16,7\%) Stakeholder, bentuk jalur $16(26,7)$ Stakeholder.

Adapun Jenis vegetasi untuk RTH di sekitar bangunan perkantoran, sekolah, pemukiman adalah:

Tabel 5. Jenis vegetasi untuk RTH di sekitar bangunan perkantoran, sekolah,

\begin{tabular}{|c|c|c|c|}
\hline \multicolumn{4}{|c|}{$\begin{array}{c}\text { Jenis Vegetasi RTH disekitar bangunan } \\
\text { perkantoran }\end{array}$} \\
\hline NO & $\begin{array}{c}\text { Jenis Vegetasi } \\
\text { RTH }\end{array}$ & Frekwensi & Persentase \\
\hline 1 & $\begin{array}{l}\text { Rumput, } \\
\text { bunga } \\
\text { boungenfil, } \\
\text { pohon perdu, } \\
\text { (mahoni, } \\
\text { pinus, } \\
\text { tanjung) }\end{array}$ & 60 & 100 \\
\hline & Jumlah & 60 & 100 \\
\hline \multicolumn{4}{|c|}{$\begin{array}{c}\text { Jenis Vegetasi RTH disekitar bangunan } \\
\text { sekolah }\end{array}$} \\
\hline NO & $\begin{array}{l}\text { Jenis Vegetasi } \\
\text { RTH }\end{array}$ & Frekwensi & Persentase \\
\hline 1 & $\begin{array}{l}\text { Rumput, } \\
\text { bunga, pohon } \\
\text { perdu, } \\
\text { (mahoni, } \\
\text { pinus, } \\
\text { tanjung) }\end{array}$ & 25 & 41,7 \\
\hline 2 & $\begin{array}{l}\text { Rumput, } \\
\text { bunga, pohon } \\
\text { perdu, pohon } \\
\text { toga, pohon }\end{array}$ & 35 & 58,3 \\
\hline
\end{tabular}

\begin{tabular}{|c|c|c|c|}
\hline \multicolumn{4}{|c|}{ berbuah } \\
\hline & Jumlah & 60 & 100 \\
\hline \multicolumn{4}{|c|}{$\begin{array}{l}\text { Jenis Vegetasi RTH disekitar bangunan } \\
\text { pemukiman }\end{array}$} \\
\hline NO & $\begin{array}{l}\text { Jenis Vegetasi } \\
\text { RTH }\end{array}$ & Frekwensi & Persentase \\
\hline 1 & $\begin{array}{l}\text { Rumput, } \\
\text { Bungan } \\
\text { Mawar, } \\
\text { Pohon Perdu, } \\
\text { Pinus. }\end{array}$ & 28 & 46,6 \\
\hline 2 & $\begin{array}{l}\text { Rumput, } \\
\text { Bunga, Pohon } \\
\text { Perdu, Pohon } \\
\text { Toga, Pohon } \\
\text { Berbuah. }\end{array}$ & 32 & 53,4 \\
\hline & Jumlah & 60 & 100 \\
\hline
\end{tabular}

RTH disekitar bangunan perkantoran, Ada 60 Stakeholder yang dijadikan sampel penelitian yang menyatakan Rumput, bunga boungenfil, pohon perdu, (mahoni, pinus, tanjung), 60 (100\%) Stakeholder. Pada tabel Jenis vegetasi untuk RTH disekitar bangunan sekolah, Ada 60 Stakeholder yang dijadikan sampel penelitian yang menyatakan Rumput, bunga, pohon perdu, (mahoni, pinus, tanjung), 25 (41,7 \%) Stakeholder, Rumput, bunga, pohon perdu, pohon toga, pohon berbuah 35 (58,3\%) Stakeholder. Pada tabel Jenis vegetasi untuk RTH disekitar bangunan pemukiman, Ada 60 Stakeholder yang dijadikan sampel penelitian yang menyatakan Rumput, Bungan Mawar, Pohon Perdu, Pinus 28 (46,6 \%) Stakeholder, Rumput, Bunga, Pohon Perdu, Pohon Toga, Pohon Berbuah 32 (53,4\%) Stakeholder.

Tabel 6. Jenis Vegetasi Hutan dan Taman Kota Untuk Ruang Terbuka

\begin{tabular}{|c|c|c|c|}
\hline \multicolumn{4}{|c|}{ Jenis Vegetasi Hutan Kota Untuk Ruang Terbuka } \\
\hline NO & $\begin{array}{c}\text { Jenis Vegetasi } \\
\text { RTH }\end{array}$ & Frekwensi & Persentase \\
\hline 1 & $\begin{array}{l}\text { Pohon Mahoni, } \\
\text { Tanjung, Pinus, } \\
\text { Beringin, } \\
\text { Flambonyat }\end{array}$ & 60 & 100 \\
\hline & Jumlah & 60 & 100 \\
\hline \multicolumn{4}{|c|}{$\begin{array}{l}\text { Jenis Vegetasi Taman Kota Untuk Ruang } \\
\text { Terbuka }\end{array}$} \\
\hline NO & Jenis Vegetasi & Frekwensi & Persentase \\
\hline
\end{tabular}




\begin{tabular}{|c|c|c|c|}
\hline \multicolumn{3}{|c|}{ RTH } & \\
\hline 1 & $\begin{array}{l}\text { Rumput, } \\
\text { Bungan } \\
\text { Kamboja, Pohon } \\
\text { Mahoni, Palem, } \\
\text { Pinus. }\end{array}$ & 35 & 58,3 \\
\hline 2 & $\begin{array}{l}\text { Rumput, Bunga } \\
\text { Kamboja, } \\
\text { tanjung, } \\
\text { Beringin, } \\
\text { Flambonyat. }\end{array}$ & 25 & 41,7 \\
\hline & Jumlah & 60 & 100 \\
\hline
\end{tabular}

Hutan Kota Untuk Ruang Terbuka disekitar bangunan perkantoran, Ada 60 Stakeholder yang dijadikan sampel penelitian yang menyatakan Pohon Mahoni, Tanjung, Pinus, Beringin, Flambonyat. 60 (100\%) Stakeholder.

Pada tabel Jenis vegetasi untuk Taman Kota Untuk Ruang Terbuka disekitar bangunan perkantoran, Ada 60 Stakeholder yang dijadikan sampel penelitian yang menyatakan Rumput, Bunga Kamboja, Pohon Mahoni, Palem, Pinus. 35 (58,3\%) Stakeholder. Rumput, Bunga Kamboja, tanjung, Beringin, Flambonyat 25 (41,7\%) Stakeholder.

Adapun Posisi RTH terhadap bangunan Perkantoran, Sekolah, Pemukiman adalah:

Tabel 7. Posisi RTH terhadap bangunan

Perkantoran, Sekolah, Pemukiman

\begin{tabular}{|c|c|c|c|}
\hline \multicolumn{4}{|c|}{ Posisi RTH terhadap bangunan Perkantoran } \\
\hline NO & Posisi RTH & Frekwensi & Persentase \\
\hline 1 & Depan & 25 & 41,6 \\
\hline 2 & Samping & 15 & 25 \\
\hline 3 & Belakang & 20 & 33,4 \\
\hline & Jumlah & 60 & 100 \\
\hline \multicolumn{4}{|c|}{ Posisi RTH terhadap bangunan Sekolah } \\
\hline NO & Posisi RTH & Frekwensi & Persentase \\
\hline 1 & Depan & 23 & 38,4 \\
\hline 2 & Samping & 17 & 28,3 \\
\hline 3 & Belakang & 20 & 33,3 \\
\hline & Jumlah & 60 & 100 \\
\hline \multicolumn{4}{|c|}{ Posisi RTH terhadap bangunan Pemukiman } \\
\hline NO & Posisi RTH & Frekwensi & Persentase \\
\hline 1 & Depan & 25 & 41,7 \\
\hline 2 & Samping & 20 & 33,3 \\
\hline 3 & Belakang & 15 & 25 \\
\hline & Jumlah & 60 & 100 \\
\hline
\end{tabular}

Posisi RTH terhadap bangunan disekitar perkantoran di Kota Baubau adalah posisi depan perkantantoran. Ada 60 Stakeholder yang dijadikan sampel penelitian yang menyatakan posisi depan $25(41,7 \%)$ Stakeholder. Posisi samping 15 (25\%) Stakeholder. Posisi belakang 20 (33,3\%) Stakeholder. Posisi RTH terhadap bangunan disekitar sekolah di Kota Baubau adalah posisi depan. Ada 60 Stakeholder yang dijadikan sampel penelitian yang menyatakan posisi depan $23(38,4 \%)$ Stakeholder. Posisi samping 17 (28,3\%) Stakeholder. Posisi belakang 20 (33,3\%) Stakeholder. Posisi RTH terhadap bangunan disekitar pemukiman di Kota Baubau adalah posisi depan. Ada 60 Stakeholder yang dijadikan sampel penelitian yang menyatakan posisi depan 25 (41,7\%) Stakeholder. Posisi samping 20 (33,3\%) Stakeholder. Posisi belakang 15 (25\%) Stakeholder.

Adapun hewan-hewan yang ada di RTH di sekitar perkantoran, sekolah, pemukiman adalah:

Tabel 8. Hewan-hewan yang ada di RTH di sekitar perkantoran, sekolah, pemukiman

\begin{tabular}{|c|c|c|c|}
\hline \multicolumn{4}{|c|}{$\begin{array}{c}\text { Hewan-hewan yang ada di RTH di sekitar } \\
\text { perkantoran }\end{array}$} \\
\hline NO & Posisi RTH & Frekwensi & Persentase \\
\hline 1 & $\begin{array}{l}\text { Burung, } \\
\text { Serangga }\end{array}$ & 40 & 66,7 \\
\hline 2 & Ikan Hias & 20 & 33,3 \\
\hline & Jumlah & 60 & 100 \\
\hline \multicolumn{4}{|c|}{$\begin{array}{c}\text { Hewan-hewan yang ada di RTH di sekitar } \\
\text { sekolah }\end{array}$} \\
\hline NO & Posisi RTH & Frekwensi & Persentase \\
\hline 1 & $\begin{array}{l}\text { Burung, } \\
\text { Serangga }\end{array}$ & 35 & 41,7 \\
\hline 2 & Ikan Hias & 25 & 58,3 \\
\hline & Jumlah & 60 & 100 \\
\hline \multicolumn{4}{|c|}{$\begin{array}{c}\text { Hewan-hewan yang ada di RTH di sekitar } \\
\text { pemukiman }\end{array}$} \\
\hline NO & Posisi RTH & Frekwensi & Persentase \\
\hline 1 & $\begin{array}{l}\text { Burung Pipit } \\
\text { benggala, } \\
\text { serangga (kupu- } \\
\text { kupu) }\end{array}$ & 35 & 41,7 \\
\hline 2 & Ikan Hias koki & 25 & 58,3 \\
\hline & Jumlah & 60 & 100 \\
\hline
\end{tabular}

di RTH di sekitar perkantoran, Ada 60 Stakeholder yang dijadikan sampel 
penelitian yang menyatakan Burung, Serangga $40(66,7 \%)$ Stakeholder. Ikan Hias 20 (33,3\%) Stakeholder. Pada tabel hewan-hewan yang ada di RTH di sekitar sekolah , Ada 60 Stakeholder yang dijadikan sampel penelitian yang menyatakan Burung, Serangga 35 (41,7\%) Stakeholder. Ikan Hias 25 (58,3\%) Stakeholder. Pada tabel hewan-hewan yang ada di RTH di sekitar sekolah, Ada 60 Stakeholder yang dijadikan sampel penelitian yang menyatakan Burung Pipit benggala, serangga (kupu-kupu) 35 $(41,7 \%)$ Stakeholder. Ikan Hias koki 25 (58,3\%) Stakeholder.

Tabel 9. Hewan yang ada di Hutan Kota dan Taman Kota untuk Ruang Terbuka

\begin{tabular}{cccc}
\hline \multicolumn{4}{c}{ Hewan Yang Ada Di Hutan Kota Untuk Ruang } \\
Terbuka
\end{tabular}

\begin{tabular}{clcc}
\hline \multicolumn{4}{c}{ Hewan Yang Ada Di Taman Kota Untuk Ruang } \\
Terbuka
\end{tabular}

hutan kota untuk ruang terbuka, Ada 60 Stakeholder yang dijadikan sampel penelitian yang menyatakan Burung Pipit benggala, serangga (kupu-kupu) 35 $(41,7 \%) \quad$ Stakeholder. Burung Pipit Benggala, Rusa 25 (58,3\%) Stakeholder. Pada tabel hewan yang ada di hutan kota untuk ruang terbuka, Ada 60 Stakeholder yang dijadikan sampel penelitian yang menyatakan Burung, Serangga 32 (53,3\%) Stakeholder. Burung, Ikan Hias 28 (36,7\%) Stakeholder

Adapun jarak hutan kota dan taman kota terhadap pemukiman masyarakat di kota Baubau adalah:
Tabel 10. Jarak hutan kota dan taman kota terhadap pemukiman masyarakat di kota Baubau

\begin{tabular}{|c|c|c|c|}
\hline \multicolumn{4}{|c|}{ Bentuk RTH disekitar bangunan Perkantoran } \\
\hline NO & Bentuk RTH & Frekwensi & Persentase \\
\hline 1 & $4 \mathrm{~km}$ & 5 & 8,3 \\
\hline 2 & $3 \mathrm{~km}$ & 10 & 16,7 \\
\hline 3 & $2 \mathrm{~km}$ & 24 & 40 \\
\hline 4 & $1 \mathrm{~km}$ & 17 & 28,3 \\
\hline 5 & $0,5 \mathrm{~km}$ & 4 & 6,7 \\
\hline & Jumlah & 60 & 100 \\
\hline \multicolumn{4}{|c|}{ Bentuk RTH disekitar bangunan Perkantoran } \\
\hline NO & Bentuk RTH & Frekwensi & Persentase \\
\hline 1 & $3 \mathrm{~km}$ & 5 & 8,3 \\
\hline 2 & $2 \mathrm{~km}$ & 10 & 16,7 \\
\hline 3 & $1 \mathrm{~km}$ & 24 & 40 \\
\hline 4 & $0,5 \mathrm{~km}$ & 17 & 28,3 \\
\hline 5 & $0,3 \mathrm{~km}$ & 4 & 6,7 \\
\hline & Jumlah & 60 & 100 \\
\hline
\end{tabular}
pemukiman masyarakat dalam penelitian ini adalah $2 \mathrm{~km}-4 \mathrm{~km}$ dari pemukiman penduduk (masyarakat). Ada 60 Stakeholder yang dijadikan sampel penelitian yang menyatakan jarak hutan kota terhadap pemukiman $4 \mathrm{~km}$ ada 5 $(8,3)$ stakeholder. Jarak hutan kota terhadap pemukiman $3 \mathrm{~km}$ ada $10(16,7 \%)$ stakeholder. Jarak hutan kota terhadap pemukiman $2 \mathrm{~km}$ ada $24 \quad(40 \%)$ stakeholder. Jarak hutan kota terhadap pemukiman $1 \mathrm{~km}$ ada $17 \quad(28,3 \%)$ stakeholder. Jarak hutan kota terhadap pemukiman $0,5 \mathrm{~km}$ ada $4 \quad(6,7 \%)$ stakeholder. Untuk jarak taman kota dengan pemukiman masyarakat dalam penelitian ini adalah $1 \mathrm{~km}$ dari pemukiman penduduk (masyarakat). Ada 60 Stakeholder yang dijadikan sampel penelitian yang menyatakan jarak hutan kota terhadap pemukiman $3 \mathrm{~km}$ ada $5(8,3)$ stakeholder. Jarak hutan kota terhadap pemukiman $3 \mathrm{~km}$ ada $10(16,7 \%)$ stakeholder. Jarak hutan kota terhadap pemukiman $1 \mathrm{~km}$ ada $24 \quad(40 \%)$ stakeholder. Jarak hutan kota terhadap pemukiman 0,5 $\mathrm{km}$ ada 17 (28,3\%) stakeholder. Jarak hutan kota terhadap pemukiman $0,3 \mathrm{~km}$ ada $4 \quad(6,7 \%)$ stakeholder. 


\section{PEMBAHASAN}

Untuk luas areal yang digunakan untuk ruang terbuka hijau disekitar perkantoran di kota Baubau adalah berkisar antara $20 \%$ - 50\% dari luas lahan yang termanfaatkan dari luas bangunan. Keberadaan ruang terbuka untuk hutan kota ditiap kecamatan sangat penting dalam mengendalikan dan memelihara integrites dan kualitas lingkungan. Bentuk ruang terbuka hijau merupakan suatu deteminan untuk bentuk kota, artinya 20\%-50\% dari seluruh luas kota diperuntukan ruang terbuka hijau (Ardi, 2008). Bentuk ruang terbuka hijau disekitar perkantoran Baubau yang berbentuk lingkaran, leter $\mathrm{L}$, leter $\mathrm{U}$, bujur sangkar dan jalur masih merupakan bentuk yang masih melekat di masyarakat kota Baubau didasarkan atas pengalaman dan budaya masyarakat setempat. Jenis vegetasi untuk RTh di sekitar perkantoran di Kota Baubau adalah vegetasi rumput, bunga, pohon perdu untuk vegetasi ini sangat di sukai oleh masyarakat jareba vegetasi tersebut merupakan pendukung dan penambah nilai kualitas lingkungan. Untuk posisi RTH terhadap bangunan perkantoran sangat mendukung untuk meningkatkan kerapian, keteraturan, meningkatkan kenyamanan dan meningkatkan keindahan kantor. Untuk hewan RTH yang ada disekotar perkantoran di kota Baubau adalah hewan burung dan serangga, ikan hias.

Untuk luas areal RTH disekitar bangunan sekolah yang fungsional dalam suatu sistem perkotaan maka luasnya berkisar antara $20 \%-50 \%$ dari luas lahan yang termanfaatkan untuk bangunan fisik. Keberadaan ruang terbuka untuk hutan kota ditiap kecamatan sangat penting dalam mengendalikan dan memelihara integrites dan kualitas lingkungan. Untuk luas areal RTH untuk ditumbuhi oleh pepohonan dengan persentase ideal $20-40 \%$ dari luas bidang tanah termasuk yang ditempati (Nurisjah, 1992). Bentuk ruang terbuka hijau di sekitar bangunan sekolah di kota Baubau yang berbentuk lingkaran, leter L, leter $\mathrm{U}$, bujur sangkar dan jalur masih merupakan bentuk yang masih melekat di masyarakat kota Baubau didasarkan atas pengalaman dan budaya masyarakat setempat. Untuk jenis vegetasi untuk RTH di sekitar bangunan sekolah adalah rumput, bungam pohon perdu, mahoni, tanjung, pohon toga, dan pohon berbuah, untuk jenis vegetasi yang cocok untuk tumbuh yaitu vegetasi mahoni, yang sementara dipublikasikan sebagai tamnaman wajib bagi sekolah yang ada di kota Baubau (Dinas pertamanan, kebersihan, pemadam, kebakaran Kota Baubau). Untuk posisi RTH di sekotar bagunan sekolah adalah posisi depan, belakang, samping. Posisi tersebut memiliki nilai estetika dan juga dapat memberi rasa nyaman pada siang hari, memiliki nilai positif untuk mencegah stres bagi guru dan juga dapat memberi rasa nyaman pada siang hari. Untuk hewan RTH yang ada di sekitar bangunan sekolah di kota Baubau hwan burung dan serangga, ikan hias. Hewan ini sudah mulai berkurang di sebabkan sudah kurangnnya tanaman dan pohon sebagai bahan makanan untuk hewan tersebut.

Untuk luas areal RTH disekitar bangunan pemukiman yang fungsional dalam suatu sistem perkotaan maka luasnya berkisar antara 20\% - 50\% dari luas lahan yang termanfaatkan untuk bangunan fisik, Keberadaan ruang terbuka untuk hutan kota ditiap kecamatan sangat penting dalam mengendalikan dan memelihara integrites dan kualitas lingkungan. RTH adalah suatu ruang terbuka yang 
ditumbuhi pepohonan dengan presentasi ideal $20-30 \%$ dari luas bidang tanah yang tempati bangunan rumah, misalnya halaman rumah (Bos Ariadi, 2005) Bentuk ruang terbuka hijau di sekitar bangunan sekolah di kota Baubau yang berbentuk lingkaran, leter L, leter $\mathrm{U}$, bujur sangkar dan jalur masih merupakan bentuk yang masih melekat di masyarakat kota Baubau didasarkan atas pengalaman dan budaya masyarakat setempat. Untuk jenis vegetasi untuk RTH di sekitar bangunan pemukiman adalah rumput, bunga, pohon perdu, dan pohon toga, pohon berbuah. Posisi ruang terbuka hijau di sekitar bangunan pemukiman di kota Baubau yaitu posisi depan, belakang, samping, masyarakat masih sangat suka dengan posisi tersebut dan masih merupakan bentuk yang masih melekat di masyarakat kota Baubau didasarkan atas pengalaman dan budaya masyarakat setempat. Untuk hewan RTH yang ada disekitar pemukiman di kota Baubau adalah hewan burung dan serangga, ikan hias. Hewan ini sangat di sukai masyarakat akan menambah suasanan rasa nyaman dan bersahabat dan pelepas strees dan hobi masyarakat.

Untuk medapatkan ruang terbuka untuk hutan kota di tiap kecamatan di kota baubau yang fungsional dalam suatu sistem perkotaan maka luasnya berkisar antara $10 \%-50 \%$ dari luas lahan yang termanfaatkan untuk bangunan fisik ditiap kecamatan. Keberadaan ruang terbuka untuk hutan kota ditiap kecamatan sangat penting dalam mengendalikan dan memelihara integrites dan kualitas lingkungan. Bentuk hutan kota yaitu jalur, menyebar, bergerombol atau menumpuk mempunaui kemampuan untuk meresapkan air ang tinggi. Efektivitas RTH yang tinggi diperoleh melalui penutupan tanah dalam betuk hutan, karena dapat evapotranspirasi RTH, sehingga kemungkinan untuk menyimpan air dalam tanah semakin besar (Nurisjah, 1992) Bahwa jenis vegetasi yang ada di hutan kota adalah pohon mahoni, tanjung, pinus, flamboyan. Vegetasi ini sangat mendukung untuk manfaat ekologis, sosial budaya, dan arsirtektural yang dapat memberikan manfaat bagi masyarakat. Untuk hewan yang ada di hutan kota Baubau adalah hewan burung dan serangga, rusa. Untuk hewan ini mulai berkurang di akibatkan dari tempat hidup maupun tempat makan hewan ini sudah berkurang di akibatkan pembangunan fisik yang dilakukan oleh pihak-pihak tertentu yang tidak melihat dampaknya dan pemburuan hewan ini diakibatkan masalah ekonomi. Untuk mendapatkan hutan kota ditiap kecamatan di kota Baubau yang fungsional dalam suatu sistem perkotaan maka jarak antara $0,5 \mathrm{~km} \mathrm{-} 4 \mathrm{~km}$ dari pemukiman masyarakat, semakin jauh jarak hutan kota dengan pemukiman masyarakat semakin baik karena pengembangan dan fungsinya yang tetap sebagai penghasil oksigen terbesar.

Untuk medapatkan ruang terbuka untuk taman kota di kota baubau yang fungsional dalam suatu sistem perkotaan maka luasnya berkisar antara 10\%-50\% dari luas lahan yang termanfaatkan untk bangunan fisik ditiap kecamatan. Keberadaan ruang terbuka untuk hutan kota sangat penting dalam mengendalikan dan memelihara integrites dan kualitas lingkungan, memiliki nilai keindahan dan dapat sebagai tempat reakreasi. RTH adalah suatu ruang terbuka yang ditumbuhi pepohonan dengan presentasi ideal 20$30 \%$ dari luas bidang tanah yang tempati bangunan rumah, misalnya halaman rumah (Bos Ariadi, 2005). Bentuk taman kota yaitu lingkaran, bujursangkar, bergerombol dan jalur akan memberikan 
nilai estetika dapat meningkatkan kerapian dan keteraturan kota, meningkatkan kenyaman kota, dan meningkatkan keindahan kota. Jenis vegetasi untuk taman kota adalah rumput, bunga, pohon mahoni, palem, pinus, tanjung, beringin, dan pohon flamboyan. Untuk hewan yang ada ditaman kota untuk ruang terbuka di kota Baubau adalah hewan burung, serabgga, dan ikan hias. Keberadaan taman kota juga dapat memberikan dampat positif terhadap perkembangan hwan. Untuk mendaptkan taman kota di kota Baubau yang fungsional dalam suatu sistem perkotaan maka jarak antara $0.3 \mathrm{~km}-3$ $\mathrm{km}$ dari pemukiman masyarakat.

\section{KESIMPULAN}

Areal ruang terbuka hijau (RTH) di sektar perkantoran di kota Baubau adalah berkisar antara 5\%-10\%, ruang terbuka hijau (RTH) di sekitar pemukiman di kota Baubau adalah berkisar atara 5\%-10\%, ruang terbuka hijau (RTH) di sekitar sekolah di kota Baubau berkisar 10\%-50\%. Untuk RTH di sekitar perkantoran, pemukiman, dan sekolah di kota Baubau belum memadai sesuai dengan inmendagri no 14 tahun 1988 adalah $40 \%-60 \%$ total area harus di hijaukan.

Areal ruang terbuka hijau (RTH) untuk taman kota di kota Baubau terletak di BWK I dengan luas areal $5 \%-10 \%$ dari luas wilayah, BWK II $5 \%-10 \%$ dari luas wilayah, BWK III tidak ada taman kota BWK IV, BWK v, BWK VI 40\% - 60\% hutan. Untuk taman kota di BWK I yang dijadikan ruang publik yaitu pantai kamali dan bukit kolema terletak BWK II yang semuanya hanya $5 \%$ dari luas lahan yang dihijaukan. Areal ruang terbuka hijau (RTH) untuk hutan kota terletak di BWK I dengan luas 10\%-15\% luas wilayah, BWK II 5\%-10\% dari luas wilayah, BWK III 5\%-10\% dari wilayah, BWK IV, BWK V, BWK VI $40 \%-60 \%$ dari luas wilayah hutan. Areal ruang terbuka untuk taman kota dan hutan kota di Kota Baubau belum memadai sesuai dengan inmedagri no 14 tahun 1988 adalah $40 \%-60 \%$ total areal harus dihijaukan yaitu untuk BWK I, II dan III.

Areal ruang terbuka untuk taman kota yang direncanakan untuk kota Baubau adalah 30\%-50\% dari luas wilayah untu BWK I. BWK II, BWK III. Bentuk taman kota adalah bergerombol yaitu taman kota yang komunitas vegetasinya terkonsentrasi pada lahan tertentu dan jumlah pohon minimal 100 pohon.

Areal ruang terbuka untuk hutan kota yang direncanakan untuk kota Baubau adalah 20\%-40\% untuk BWK I. BWK II, BWK III. Bentuk yang direncakan adalah bentuk jalur untuk pinggiran suangai, jalan, pantai, pemakaman umum dan lapangan olahraga. Hutan kota terletak di BWK IV, BWK V, dan BWK VI sebaiknya di pertahankan.

\section{DAFTAR PUSTAKA}

Ardi, M. (2008). Straregi Membangun

Perumahan Yang Berwawasan

Lingkungan. Buletin Nasional.

Bos Ariadi, M. (2005). Analisis

Kebutuhan Ruan Gterbuka Hijau

Berdasarkan Kebutuhan Oksigen dan

Air di Kota Depok. Institut

Pertanian Bogor.

Brundtland. (1978). Hari Depan Kita

Bersama, Komisi Dunia untuk 
Lingkungan dan Pembangunan.

Jakarta: Gramedia.

Nurisjah, S. (1992). Konsepsi Ruang terbuka hijau (RTH) Kawasan

Perkotaan. Pelatihan RTH Kota

Bogor. Bogor: Studio Arsitektur Lanskap IPB. 